\title{
EVALUATION OF SLOVAK WINTER WHEAT QUALITY IN TERMS OF PUROINDOLINE GENES
}

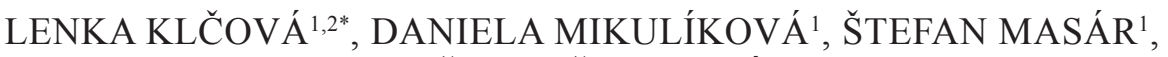 \\ ALŽBETA ŽOFAJOVÁ ${ }^{1}$
}

\author{
${ }^{1}$ National Agricultural and Food Centre \\ ${ }^{2}$ Constantine The Philosopher University in Nitra
}

KLČOVÁ, L. - MIKULÍKOVÁ, D. - MASÁR, Š. - ŽOFAJOVÁ, A.: Evaluation of Slovak winter wheat quality in terms of puroindoline genes. Agriculture (Pol'nohospodárstvo), vol. 61, 2015, no. 3, pp. 88-96.

\begin{abstract}
The grain hardness of 100 current and 24 old superior Slovak winter wheat cultivars was studied at molecular level. Using polymerase chain reactions (PCRs), normal and null alleles of both puroindoline Pina and Pinb genes were identified. Three different genotypes were found: 1) normal allele of both genes (dominant wild type with soft endosperm) - Pina-D1a/Pinb-D1a; 2) normal allele of the Pina gene and null allele of the Pinb gene - PinaD1a/Pinb-D1b; and 3) null allele of the Pina gene and normal allele of the Pinb gene Pina-D1b/Pinb-D1a. No Slovak current as well as old wheat cultivar had together null allele of both puroindoline genes. The frequencies of wild-type Pinb-D1a and null Pinb-D1b allele in current cultivars were $62.0 \%$ and $38.0 \%$, respectively, whilst in
\end{abstract}

old cultivars, $8.3 \%$ and $91.7 \%$, respectively. Regarding null allele Pina-D1b of puroindoline Pina gene, only in Rheia current cultivar, one was found. All other cultivars had wild-type Pina-D1a allele. Alacris, Alana, Axis, Balada, Blava, Bona Dea, Bruta, Charger, Hana, Ilona, IS Karpatia, Ludwig and Sulamit current cultivars were selected as donors of the null Pinb-D1b allele for molecular breeding in order to improve the grain hardness as important wheat quality trait. Statistically significant correlations between null Pinb-D1b allele and grain size as well as colour were found. In comparison with wild type, cultivars with this null allele have paler and longer grain with higher length-to-width ratio and lighter grain colour.

Key words: current and old Slovak cultivars, grain size and colour, null allele, polymerase chain reaction, puroindoline genes, winter wheat

The variation in grain hardness (hard or soft endosperm texture) is one of the most important traits that determine the utilisation and marketing of hexaploid wheat. Wheat grain texture is determined by the degree of grain hardness or softness. Hardness is defined as 'difficulty to penetrate or reduce to smaller fragments'. This characteristic strongly influences the functionality of wheat and affects a range of parameters including the milling (tempering, milling yield, flour particle size, shape and density of flour particles), baking and end-use properties (Giroux \& Morris 1998; Morris 2002). An important functional

difference between hard and soft wheats is in their water absorption. Hard wheat varieties are typically higher in protein content (12-15\%) and stronger gluten-forming proteins than soft wheat ones $(5-10 \%)$. Grain hardness was negatively correlated with break flour yield, flour yield and mixing score and positively correlated with flour ash (Martin et al. 2001). Grain hardness was not correlated with loaf volume or crumb grain score (Hogg et al. 2005).

Wheat hardness (the degree of adhesion between the starch granules and the protein matrix) is regulated by the friabilin. The discovery of this $15-\mathrm{kDa}$

Mgr. Lenka Klčová (*Corresponding author), National Agricultural and Food Centre - Research Institute of Plant Production, Bratislavská cesta 122, 92168 Piešt’any, Slovak Republic. E-mail: 1.klcova@vurv.sk

Constantine The Philosopher University, Faculty of Natural Sciences, A. Hlinku 1, 94901 Nitra, Slovak Republic 
protein provided a biochemical way to distinguish between hard and soft wheats. It is present in larger amounts in soft wheats compared to hard ones and consists of three major polypeptides (Gautier et al. 1994; Rahman et al. 1994; Giroux \& Morris 1997): puroindoline-a (Pina), puroindoline-b (Pinb) and grain softness protein 1 (Gsp-1). A single locus Hardness $(\mathrm{Ha})$ for the grain endosperm texture was identified at the short arm of chromosome 5D (Turnbull et al. 2003). They designated the gene Hard$n e s s$, with the soft allele $H a$ and the hard allele $h a$. Softness is a dominant trait.

Previous studies suggested that the grain hardness is correlated with the soft type Pina and Pinb, not total puroindoline (Swan et al. 2006). Igrejas et al. (2001) found Pinb to be more closely correlated with grain hardness than Pina. The soft grain texture in wheat is the result of both puroindoline genes occurrence in the wild-type form. When one of the puroindolines is either absent or altered by various mutations, it results in a hard texture. Gene sequence variation and mutations of both puroindoline genes account for the majority of variation in the wheat grain texture.

To date, in winter wheat, 16 and 24 recessive null alleles were identified at the Pina and Pinb loci, respectively (Bhave \& Morris 2008). However, still - from time to time - new mutations of both puroindoline genes are discovered (Chen et al. 2009). Most of mutate alleles occur only isolated in some localities (Lilemo \& Morris 2000; Chen et al. 2005, 2006), for instance, in Northern Europe (Pinb-D1c allele), Sweden and Netherlands (Pinb-D1d), a few of Chinese landrances (Pina-D1l, PinaD1n, Pinb$D 1 p$ ), Jiangsu province (Pina-D1m) and Guizhou province (Pinb-D1t).

Some of the alleles result in particular single nucleotide change or deletion at various positions in the coding region, another result in the 'stop' codon TGA (tryptophan). The dominant wild-type alleles (Pina-Dla and Pinb-Dla), as well as recessive $P$ in $b-D 1 b$ null allele, occur most frequently. The Pina-D1 $a$ allele (wild type) is present in all soft hexaploid and possibly all hard hexaploid wheats carrying the hardness mutation in puroindoline-b. The Pinb-D1a allele (wild type) occurs in all soft hexaploid and possibly in all hard hexaploid wheats carrying the mutation in puroindoline-a. The Pinb-
$D 1 b$ is a 'loss of function' mutation. It is prevalent amongst a wide set of both recent and historical cultivars (Giroux \& Morris 1997).

Grain hardness is largely controlled by genetic factors; however, it can be also partly affected by the environmental and other factors allowing $\mathrm{N}$ management, tillage system, fertiliser as well as fallow management, pest infestations, moisture, gliadin composition, lipid, starch and pentosan content (Huebner \& Gaines 1992; Peterson et al. 1992; Lyon \& Shelton 1999; Konopka et al. 2005b; Oury et al. 2015).

Owing to the lack of information about hardness of Slovak winter wheat cultivars at molecular level, the specific objective of this study was to discover allelic variation of both puroindoline genes in current and old Slovak cultivars. Another aim was to recognize the relation of glycine $\rightarrow$ serine point mutation to the grain size and colour as well as to determine suitable cultivars as donors of the Pinb-D1b null allele for marker-assisted selection (MAS) in order to manipulate the grain hardness.

\section{MATERIAL AND METHODS}

\section{Plant materials}

Seed samples (200 grains of each cultivar) of 100 current (registered in the Slovak National List of Varieties) and 24 old superior Slovak winter wheat cultivars were obtained from The Gene Bank of Slovak Republic in Piešt'any (kindly provided by Dr. Pavol Hauptvogel). Following the published data (McIntosh et al. 2003), Bolero cultivar (Italy) was used as standard for the detection of normal allele of both puroindoline genes. In addition, Amidon cultivar (USA), which has null allele (Pina-D1b) of the Pina gene, as well as Brasilia (Italy) and Pascal (France) cultivars possessing null allele (Pinb-D1b) of the Pinb gene were used.

\section{Genomic DNA preparation}

DNA was extracted from $100 \mathrm{mg}$ of young wheat leaf tissue using the DNeasy Plant Mini Kit (Qiagen, Hilden, Germany) according to the manufacturer's instructions. 


\section{Primers and PCR conditions}

Amplification of the Pina and Pinb puroindoline genes was performed using sequence-specific primers Pina-D1-F, Pina-D1-R, Pinb-D1-F, Pinb-D1-R, Pinb-glyR and Pinb-serR (Gautier et al. 1994; Giroux \& Morris 1997; Tranquilli et al. 1999). The sequences for forward $(\mathrm{F})$ and reverse $(\mathrm{R})$ primers were as follows:

Pina-D1-F: 5'-CCC TGT AGA GAC AAA GCT AA-3'

Pina-D1-R: 5'-TCA CCA GTA ATA GCC AAT AGT G-3'

Pinb-D1-F: 5'-ATG AAG ACC TTA TTC CTC CTA-3'

Pinb-D1-R: 5'-TCA CCA GTA ATA GCC ACT AGG GAA-3'

Pinb-glyR: 5'-CTC ATG CTC ACA GCC GCC-3' Pinb-serR: 5'-CTC ATG CTC ACA GCC GCT-3'

The polymerase chain reactions (PCRs) were performed in a final reaction volume of $15 \mu \mathrm{lusing}$ $25 \mathrm{ng}$ of genomic DNA, $1 \times$ PCR buffer, $1.5 \mathrm{mM}$ $\mathrm{MgCl}_{2}, 0.2 \mathrm{mMdNTP}, 0.2 \mu \mathrm{M}$ of each forward and reverse primers and $0.8 \mathrm{U}$ of Taq DNA polymerase (Invitrogen).

The amplification conditions for Pina included initial denaturation at $94^{\circ} \mathrm{C}$ for $3 \mathrm{~min}$, followed by 37 cycles at $94^{\circ} \mathrm{C}$ for $90 \mathrm{~s}$, at $55^{\circ} \mathrm{C}$ for $90 \mathrm{~s}$, at $72^{\circ} \mathrm{C}$ for $2 \mathrm{~min}$ and final extension at $72^{\circ} \mathrm{C}$ for $10 \mathrm{~min}$. To amplify Pinb, annealing temperature was raised up to $58^{\circ} \mathrm{C}$. PCRs were conducted using PTC-200 thermal cycler (MJ Research Inc., Waltham).

Amplified PCR products were analysed on $1.4 \%$ agarose gels, stained with ethidium bromide. Amplification is observed only for the wild-type Pina-D1a, yielding 330 bp fragment; null allele Pina-D1b amplifies no band.

After amplification of a 447-bp segment of the Pinb-D1 gene using primers designed by Gautier et al. (1994), the PCR product was digested by the restriction endonuclease BsrBI. The enzyme recognises the sequence with the glycine $\rightarrow$ serine mutation but not the sequence without the mutation. After digestion, fragments of $320 \mathrm{bp}$ are expected for genotypes lacking the mutation (normal allele), whilst fragments of $200 \mathrm{bp}$ are expected for genotypes carrying the null allele for hard texture (Tranquilli et al. 1999). For differen- tiation of normal Pinb-Dla from null Pinb-D $1 b$ allele, primers Pinb-glyR/Pinb-serR and PinbD1-F were used (Gautier et al. 1994).

\section{Grain parameters assessment}

In triplicate, 36 grains of two genetically related pairs of old wheat cultivars Slovenská B and Slovenská 777 (Slovenská B line II and Slovenská B line III as well as Slovenská 777 line I and Slovenská 777 line V) were examined for grain dimensions and 24 grains for colour. Digital image analysis (images were obtained with scanner HP Scanjet 4370, Hewlet Packard) was used to measure grain length and width (Tahir et al. 2007) as well as red, green and blue (RGB) colour components. The methods of measurement were similar as described by Tańska et al. (2005). Dimension parameters were measured in the Microsoft photo editor 3 . To determine the grain colour histograms of RGB component, the Assess Image Analysis Software for Plant Disease Quantification were used (Lamari 2002).

\section{Statistical methods}

Standard statistical testing including analysis of variance (ANOVA), general linear model, Bonferroni test and Tukey's HSD test (statistical software package SPSS ${ }^{\circledR} 11.5$ ) was used for data evaluation. The value $P<0.05$ was considered statistically significant.

\section{RESULTS AND DISCUSSION}

All 124 evaluated wheat cultivars belong to following alleles of the Pina and Pinb genes (Table 1): normal Pina-Dla and Pinb-Dla and null Pina-D $1 b$ and Pinb-DIb alleles. Concerning the Pina gene, null allele Pina-D1b, which is associated with harder texture than Pinb-D1b mutation (Morris \& Massa 2003), was found only in Rheia current cultivar. Other current cultivars, as well as old cultivars, have wild-type Pina-Dla allele. Regarding the Pinb gene, frequencies of normal (wild-type) Pinb-D1a and null Pinb-D $1 b$ allele were $62.0 \%$ and $38.0 \%$, respectively, in current cultivars, whilst $8.3 \%$ and $91.7 \%$, respectively, in historical ones. Recessive null Pinb$D 1 b$ allele was found mostly in cultivars with good bread-making quality (Alacris, Alana, Axis, Balada, 
Blava, Bona Dea, Bruta, Charger, Hana, Ilona, IS Karpatia, Ludwig, and Sulamit). Surprisingly, almost all (22 from 24) old superior cultivars were homozygous for recessive null Pinb-D1b allele. The null Pinb-D1b allele was detected in Slovenská 777 (I-IV), Stupická Bastard (I-V), Kaštická bezosinatá (I-III), Radošinská Dorada (I-V), Slovenská 200 I, Slovenská B (I and II) and Bučianska červenoklasá (I and II) cultivars. Because all varieties had normal (Pina-Dla and Pinb-D1a) or the most frequent null allele (Pina-D1b and Pinb-D1b) of both puroindoline genes, we did not look for other sporadically occurring null alleles.

Three different genotypes of puroindoline genes were found: 1) normal allele of both genes, $P i$ na-Dla/Pinb-Dla (dominant wild type with soft grain); 2) normal allele of the Pina gene and null allele of the Pinb gene, Pina-D1a/Pinb-D1b (moderately hard grain); and 3) null allele of the Pina gene and normal allele of the Pinb gene, Pina-DIb/ Pinb-D1a (very hard grain). Neither in the current nor in the old Slovak wheat cultivars we detected simultaneous presence of null alleles of Pina and
Pinb genes. Dominant wild type with soft grain was achieved in $61.0 \%$ of current cultivars and in only $8.3 \%$ of old wheat cultivars (Table 2). The genotype Pinb-D1b was detected in $38.0 \%$ of current and $91.7 \%$ of old superior cultivars. Whilst in old cultivars, the Pina-Dla/Pinb-D1b genotype with moderately hard grain dominated, in current cultivars, the dominant wild-type Pina-D1a/Pinb-D1a with soft grain associated with poorer wheat quality was more frequent. This fact points to forgetting of grain hardness importance in breeding for other wheat qualitative traits. Our results provide the possibility of Slovak wheat cultivars breeding for hardness improvement.

Obtained results from cultivars of the Slovak origin are in agreement with observations of other authors who also found the Pinb-D1b mutation as prevalent amongst a wide set of both recent and historical wheat cultivars of different origin (Giroux \& Morris 1997). The null allele has a glycine $\rightarrow$ serine substitution at position 46 in the puroindoline Pinb gene (Giroux \& Morris 1997). The Pinb-D1b allele was first characterised in the 'Chinese Spring'

T a b

The frequency of homozygous alleles in winter wheat cultivars

\begin{tabular}{|l|c|c|c|c|}
\hline \multirow{4}{*}{ Cultivars (number) } & \multicolumn{2}{|c|}{ Pina gene } & \multicolumn{2}{|c|}{ Pinb gene } \\
\cline { 2 - 5 } & $\begin{array}{c}\text { Normal allele } \\
\text { Pina-D1a } \\
{[\%]}\end{array}$ & $\begin{array}{c}\text { Null allele } \\
\text { Pina-D1b } \\
{[\%]}\end{array}$ & $\begin{array}{c}\text { Normal allele } \\
\text { Pinb-D1a } \\
{[\%]}\end{array}$ & $\begin{array}{c}\text { Null allele } \\
\text { Pinb-D1b } \\
{[\%]}\end{array}$ \\
\hline Current registered (100) & 99.0 & 1.0 & 62.0 & 38.0 \\
Old (24) & 100.0 & 0.0 & 8.3 & 91.7 \\
\hline
\end{tabular}

$\mathrm{T}$ a

The frequency of homozygous genotypes in winter wheat cultivars

\begin{tabular}{|c|c|c|}
\hline Puroindoline genotype & Current cultivars [\%] & Old cultivars [\%] \\
\hline Pina-D1a/Pinb-D1a & 61.0 & 8.3 \\
Pina-D1b/Pinb-Dla & 1.0 & 0.0 \\
Pina-D1a/Pinb-D1b & 38.0 & 91.7 \\
Pina-D1b/Pinb-D1b & 0.0 & 0.0 \\
\hline
\end{tabular}

Pina-Puroindoline-a gene; Pinb-Puroindoline- $b$ gene 
substitution line possessing the 5D chromosomes of 'Cheyenne'. Giroux \& Morris (1997) discovered that the hardness mutation is a single base change (GGC $\rightarrow$ AGC) in the codon of Gly-46, converting glycine to serine. The mutation is highly conserved and might explain the most of phenotypically hard hexaploid wheats. Lillemo and Morris (2000) showed that the prevalence of mutation might be largely related to the gene pools of interest and also the particular area of origin.

Genotypes with $P$ inb-D1b possess significantly lower flour ash content and higher milling yield than those of genotypes with Pina-D1b. For steamed bread, mean scores for loaf volume, crumb colour, width and structure and total score of Pinb-D1b genotypes were significantly higher than those of geno- types with Pina-DIb and wild-type Pinb-Dla (Chen et al. 2007).

Two old Slovak wheat cultivars, Slovenská B and Slovenská 777, had different alleles of the Pinb gene (Slovenská B line III had normal allele and Slovenská B line II the null allele, Slovenská 777 line V had normal and Slovenská 777 line I had the null allele). Therefore, we focused on comparing the width, length and RGB colour components in relation to the presence of the null and normal allele of Pinb-DIb gene in these genetically related lines of cultivars Slovenská B and Slovenská 777.

Concerning Pinb gene, significant influence on grain length, grain length-to-width ratio, width-tolength ratio and grain colour components red, green and blue in RGB colour model was found (Table

$\mathrm{T}$ a

Mean squares from ANOVA for wheat grain size and grain colour components to alleles of the Pinb gene

\begin{tabular}{|c|c|c|c|}
\hline & Variability of the Pinb gene & df & Mean squares \\
\hline \multicolumn{4}{|c|}{ Grain dimensions } \\
\hline \multirow{3}{*}{ Length } & Between groups & 1 & $8,576.053^{+}$ \\
\hline & Within groups & 46 & $1,257.283$ \\
\hline & Total & 47 & - \\
\hline \multirow{3}{*}{ Width } & Between groups & 1 & $1,313.985^{\mathrm{NS}}$ \\
\hline & Within groups & 46 & 809.291 \\
\hline & Total & 47 & - \\
\hline \multirow{3}{*}{ Length/width } & Between groups & 1 & $0.373^{++}$ \\
\hline & Within groups & 46 & 0.043 \\
\hline & Total & 47 & - \\
\hline \multirow{3}{*}{ Width/length } & Between groups & 1 & $0.018^{++}$ \\
\hline & Within groups & 46 & 0.002 \\
\hline & Total & 47 & - \\
\hline \multicolumn{4}{|c|}{ Grain colour components } \\
\hline \multirow{3}{*}{ Red } & Between groups & 1 & $18,292.563^{++}$ \\
\hline & Within groups & 142 & 303.642 \\
\hline & Total & 143 & - \\
\hline \multirow{3}{*}{ Green } & Between groups & 1 & $18,225.000^{++}$ \\
\hline & Within groups & 142 & 235.359 \\
\hline & Total & 143 & - \\
\hline \multirow{3}{*}{ Blue } & Between groups & 1 & $33,580.562^{++}$ \\
\hline & Within groups & 142 & 282.534 \\
\hline & Total & 143 & - \\
\hline
\end{tabular}

${ }^{++}$Significant at the 0.01 level; ${ }^{+}$significant at the 0.05 level; ${ }^{\text {NS }}$ not significant 
3). From Table 4, the rounder kernel in cultivars having null allele of the Pinb gene is evident. The mean values of grain length and width were 623 and 288 pixels for normal allele Pinb-D1a and 596 and 299 pixels for null allele Pinb-D1b, respectively. In comparison with normal allele Pinb-Dla, the cultivars with the null allele Pinb-D $1 b$ have significantly shorter kernel $(P<0.05)$ and lower length-to-width ratio $(P<0.01)$.

Using digital image analysis, significant differences in wheat grain size and colour were ascertained. Grain size influences milling quality of wheat (Marshall et al. 1986). Sizes together with density determine grain weight, which has a favourable effect on agronomic and flour yield of wheat (Dziki \& Laskowski 2005). Quantitative trait loci (QTL) for grain length and width in bread wheat were found on various chromosomes (Dholakia et al. 2003; Breseghello \& Sorrells 2007). From the low genetic correlation between grain length and width found, Bergman et al. (2000) deduced their independent inheritance.

In addition, cultivars with the null allele Pinb$D 1 b$ have lighter grain colour. RGB colour components in cultivars with the null allele have significantly $(P<0.01)$ higher values as compared to cultivars with normal allele (Table 5). Mean squares from general linear model and coefficient of determination $\left(\mathrm{R}^{2}\right)$ for length, width, length-to-width ratio, width-to-length ratio and colour components RGB indicate that the fitted model explains significant $(P<0.01)$ great deal of variability (Table 6). Dobraszczyk et al. (2002) indicated that grain hardness corresponds to endosperm density. Results of Konopka et al. (2005a) pointed to relationship between the endosperm colour and grain hardness in wheat cultivars. However, the authors found that environment causes variability of the protein content, hardness, vitreousness, length and size of grains, and all these can affect grains colour.

$\mathrm{T}$ a

Mean values of grain size in relation to the Pinb gene (the Bonferroni test)

\begin{tabular}{|l|l|c|c|c|c|}
\hline Grain dimensions & Allele of the Pinb gene & N & Mean & Std. error & Difference \\
\hline \multirow{2}{*}{ Length } & Normal & 24 & 623.089 & 7.027 & $26.733^{+}$ \\
& Null Pinb-D1b & 24 & 596.355 & 7.443 & - \\
\hline \multirow{2}{*}{ Width } & Normal & 24 & 288.473 & 5.426 & $-10.464^{\mathrm{NS}}$ \\
& Null Pinb-D1b & 24 & 298.937 & 6.330 & - \\
\hline \multirow{2}{*}{ Length/width } & Normal & 24 & 2.182 & 0.048 & $0.176^{++}$ \\
& Null Pinb-D1b & 24 & 2.005 & 0.036 & - \\
\hline \multirow{2}{*}{ Width/length } & Normal & 24 & 0.463 & 0.441 & $-0.039^{++}$ \\
& Null Pinb-D1b & 24 & 0.502 & 0.484 & - \\
\hline
\end{tabular}

${ }^{++}$Significant at the 0.01 level; ${ }^{+}$significant at the 0.05 level; ${ }^{\text {NS }}$ not significant

$\mathrm{T}$ a

The effect of alleles on RGB colour components in relation to the Pinb gene (Tukey's HSD test)

\begin{tabular}{|c|c|c|c|c|c|}
\hline Cultivar & Allele of Pinb gene & N & Red (R) & Green $(\mathrm{G})$ & Blue (B) \\
\hline Slovenská B III & Normal & 36 & $187.86^{\mathrm{a}}$ & $139.58^{\mathrm{a}}$ & $50.53^{\mathrm{a}}$ \\
Slovenská 777 V & Normal & 36 & $200.50^{\mathrm{a}}$ & $148.89^{\mathrm{a}}$ & $52.39^{\mathrm{a}}$ \\
Slovenská 777 I & Null Pinb-D1b & 36 & $215.42^{\mathrm{b}}$ & $166.39^{\mathrm{b}}$ & $78.72^{\mathrm{b}}$ \\
Slovenská B II & Null Pinb-D1b & 36 & $218.03^{\mathrm{b}}$ & $167.08^{\mathrm{b}}$ & $85.28^{\mathrm{b}}$ \\
\hline
\end{tabular}

Different letter $(\mathrm{a}, \mathrm{b})$ indicate statistically significant differences $(P<0.01)$ 


\section{CONCLUSIONS}

Wheat marketing system established the primary classification of hexaploid wheat based on the endosperm texture. The grain hardness is one of the most important traits and affects a range of parameters including the milling, baking and end-use properties of wheat. The aim of our work was to evaluate the grain hardness of 100 current and 24 old superior
Slovak winter wheat cultivars at molecular level and determine its relation to grain size and colour. Normal (wild-type) and null alleles of both puroindoline Pina and Pinb genes were identified using PCRs. In conclusion, no one of cultivars tested had together null allele of both Pin genes. Only one null Pina allele was identified in Slovak winter wheat cultivars. Null allele Pinb-D1b ('loss of function' mutation resulting from the replacement of glycine by serine

$\mathrm{T}$ a

Mean squares from general linear model and coefficient of determination $\left(\mathrm{R}^{2}\right)$ for length, width, length/width, width/length, and colour component red, green, blue in relation to the Pinb gene

\begin{tabular}{|c|c|c|c|c|}
\hline & Source & $\mathrm{df}$ & Mean square & $\mathrm{R}^{2}$ \\
\hline \multicolumn{5}{|c|}{ Grain dimensions } \\
\hline \multirow{4}{*}{ Length } & Model & 2 & $8,926,552.480^{++}$ & 0.997 \\
\hline & Pinb & 2 & $8,926,552.480^{++}$ & - \\
\hline & Error & 46 & $1,257,283.000$ & - \\
\hline & Total & 48 & - & - \\
\hline \multirow{4}{*}{ Width } & Model & 2 & $2,070,960.041^{++}$ & 0.991 \\
\hline & Pinb & 2 & $2,070,960.041^{++}$ & - \\
\hline & Error & 46 & 809.291 & - \\
\hline & Total & 48 & - & - \\
\hline \multirow{4}{*}{ Length/Width } & Model & 2 & $105.376^{++}$ & 0.991 \\
\hline & Pinb & 2 & $105.376^{++}$ & - \\
\hline & Error & 46 & 0.043 & - \\
\hline & Total & 48 & - & - \\
\hline \multirow{4}{*}{ Width/Length } & Model & 2 & $5.592^{++}$ & 0.991 \\
\hline & Pinb & 2 & $5.592^{++}$ & - \\
\hline & Error & 46 & 0.002 & - \\
\hline & Total & 48 & - & - \\
\hline \multicolumn{5}{|c|}{ Colour components } \\
\hline \multirow{4}{*}{ Red } & Model & 2 & $3,048,285.951^{++}$ & 0.993 \\
\hline & Pinb & 2 & $3,048,285.951^{++}$ & - \\
\hline & Error & 142 & 303.642 & - \\
\hline & Total & 144 & - & - \\
\hline \multirow{4}{*}{ Green } & Model & 2 & $1,749,779.514^{++}$ & 0.991 \\
\hline & Pinb & 2 & $1,749,779.514^{++}$ & - \\
\hline & Error & 142 & 235.359 & - \\
\hline & Total & 144 & - & - \\
\hline \multirow{4}{*}{ Blue } & Model & 2 & $337,390.562^{++}$ & 0.944 \\
\hline & Pinb & 2 & $337,390.562^{++}$ & - \\
\hline & Error & 142 & 282.534 & - \\
\hline & Total & 144 & - & - \\
\hline
\end{tabular}

${ }^{++}$Significant at the 0.01 level 
at position 46), which is prevalent amongst most of the European countries, was detected in $38.0 \%$ of current and $91.7 \%$ of old superior cultivars. Its incidence was higher in old superior in comparison with current cultivars. Statistically significant correlations between null Pinb-D1b allele and grain size as well as colour were found. The cultivars with the null allele Pinb-D1b have significantly shorter kernel, lower length-to-width ratio and lighter grain colour. We selected cultivars that would be helpful in molecular breeding programme as donors of the null allele in order to manipulate grain hardness as one of the main quality traits of winter wheat.

Acknowledgements. Supported by the Ministry of Agriculture and Rural Development of the Slovak Republic, Project GENETIMPRO. Authors thank Mrs. Jela Klčová for her excellent technical assistance.

\section{REFERENCES}

BERGMAN, C.J. - GUALBERTO, D.G. - CAMPBELL, K.G. - SORRELLS, M.E. - FINNEY, P.L. 2000. Kernel morphology variation in a population derived from a solt by hard wheat cross and associations with enduse quality traits. In Journal of Food Quality, vol. 23, pp. 391-407. DOI: 10.1111/j.1745-4557.2000. tb00566.x.

BHAVE, M. - MORRIS, C.F. 2008. Molecular genetics of puroindolines and related genes: allelic diversity in wheat and other grasses. In Plant Molecular Biology, vol. 66, pp. 205-219. DOI: 10.1007/s11103007-9263-7.

BRESEGHELLO, F. - SORRELLS, M.E. 2007. QTL analysis of kernel size and shape in two hexaploid wheat mapping populations. In Field Crops Research, vol. 101 , pp. 172-179.

CHEN, F. - BEECHER, B.S. - MORRIS, C.F. 2009. Physical mapping and a new variant of Puroindoline b2 genes in wheat. In Theoretical and Applied Genetics, vol. 120, pp. 745-751. DOI: 10.1007/s00122009-1195-y.

CHEN, F. - HE, Z. - CHEN, D. - ZHANG, C. - ZHANG, Y. - XIA, X. 2007. Influence of puroindoline alleles on milling performance and qualities of Chinese noodles, steamed bread and pan bread in spring wheats. In Journal of Cereal Science, vol. 45, pp. 59-66.

CHEN, F. - HE, Z. - XIA, X. - LILlEMO, M. - MORRIS, C.F. 2005. A new puroindoline-b mutation present in Chinese winter wheat cultivar Jingdong 11. In Journal of Cereal Science, vol. 42, pp. 267-269.

CHEN, F. - HE, Z.H. - XIA, X.C. - XIA, L.Q. - ZHANG, X.Y. - LILLEMO, M. - MORRIS, C.F. 2006. Molecular and biochemical characterization pf puroindoline-a and $\mathrm{b}$ alleles in Chinese landraces and historical cultivars. In Theoretical and Applied Genetics, vol. 112, pp. 400409. DOI: 10.1007/s00122-005-0095-z.

DHOLAKIA, B.B. - AMMIRAJU, J.S.S. - SINGH, H. LAGU, M.D. - RÖDER, M.S. - RAO, V.S. - DHALIWAL, H.S. - RANJEKAR, P.K. - GUPTA, V.S. 2003. Molecular marker analysis of kernel size and shape in bread wheat. In Plant Breeding, vol. 122, pp. 392 395. DOI: 10.1046/j.1439-0523.2003.00896.x.

DOBRASZCZYK, B.J. - WHITWORTH, M.B. - VINCENT, J.F.V. - KHAN A.A. 2002. Single kernel wheat hardness and fracture properties in relation to density and the modelling of fracture in wheat endosperm. In Journal of Cereal Science, vol. 35, pp. 245-263.

DZIKI, D. - LASKOWSKI, J. 2005. Wheat kernel physical properties and milling process. In Acta Agrophysica, vol. 6, pp. 59-71.

GAUTIER, M.F. - ALEMAN, M.E. - GUIRAO, A. MARION, D. - JOUDRIER P. 1994. Triticum aestivum L. puroindolines, two basic cysteine-rich seed proteins: cDNA sequence analysis and developmental gene expression. In Plant Molecular Biology, vol. 25, pp. 43-57. DOI: 10.1007/BF00024197.

GIROUX, M.J. - MORRIS, C.F. 1997. A glycine to serine change in puroindoline-b is associated with wheat grain hardness and low levels of starch-surface friabilin. In Theoretical and Applied Genetics, vol. 95, pp. 857-864. DOI: $10.1007 / \mathrm{s} 001220050636$.

GIROUX, M.J. - MORRIS, C.F. 1998. Wheat grain hardness results from highly conserved mutation in the friabilin components puroindoline-a and b. In Proceedings of the National Academy of Science USA, vol. 95, pp. 6262-6266.

HOGG, A.C. - BEECHER, B. - MARTIN, J.M. - MEYER, F. - TALBERT, L. - LANNING S. - GIROUX, M.J. 2005. Hard wheat milling and bread baking traits affected by the seedspecific overexpression of puroindolines. In Crop Science, vol. 45, pp 871-878. DOI: $10.2135 /$ cropsci2004.0113.

HUEBNER, F.R. - GAINES, C.S. 1992. Relation between wheat kernel hardness, environment, and gliadin composition. In Cereal Chemistry, vol. 69, pp. 148-151.

IGREJAS, G. - GABORIT, T. - OURY, F.X. - CHIRON, H. - MARION, D. - BRANLARD G. 2001. Genetic and environmental effects on puroindoline-a and puroindoline-b and their technological properties in French bread wheats. In Journal of Cereal Science, vol. 34 , pp. 37-47.

KONOPKA, I. - KOZIROK, W. - TAŃSKA M. $2005 \mathrm{a}$. Wheat endosperm hardness. Part I. Relationship to colour of kernel cross-section. In European Food Research and Technology, vol. 220, pp. 11-19. DOI: 10.1007/s00217-004-1037-8.

KONOPKA, I. - ROTKIEWICZ, D. - TAŃSKA M. 2005b. Wheat endosperm hardness. Part II. Relation to content and composition of flour lipids. In European Food Research and Technology, vol. 220, pp. 20-24. DOI: 10.1007/s00217-004-1038-7.

LAMARI, L. 2002. Assess: Image Analysis Software for plant disease quantification V1.0. In BOCK, 
C.H. - COOK, A.Z. - PARKER, P.E. (Eds) American Phytopathological Society. St. Paul 2002. ISBN 0890542961.

LILEMO, M. - MORRIS, C.F. 2000. A leucine to proline mutation in puroindoline-b is frequently present in hard wheats from Northern Europe. In Theoretical and Applied Genetics, vol. 100, pp. 1100-1107. DOI: $10.1007 / \mathrm{s} 001220051392$.

LYON, D.J. - SHELTON, D.R. 1999. Fallow management and nitrogen fertilizer influence winter wheat kernel hardness. In Crop Science, vol. 39, pp. 448-452. DOI: 10.2135/cropsci1999.0011183X0039000200025x.

MARSHALL, D.R. - MARES, D.J. - MOSS, H.J. - ELLISON, F.W. 1986. Effects of grain shape and size on milling yields in wheat. In Australian Journal of Agricultural Research, vol. 37, pp. 331-342. DOI: 10.1071/AR9860331.

MARTIN, J.M. - FROHBERG, R.C. - MORRIS, C.F. - TALBERT, L.E. - GIROUX M.J. 2001. Milling and bread baking traits associated with puroindoline sequence type in hard red spring wheat. In Crop Science, vol. 41, pp. 228-234. DOI: 10.2135/cropsci2001.411228x

McINTOSH, R.A. - DEVOS, K.M. - DUBCOVSKY, J. - MORRIS, C.F. - ROGERS, W.J. 2003. Catalogue of gene symbols for wheat. http://wheat.pw.usda.gov/ ggpages/wgc/2003upd.html (15.2.2008).

MORRIS, C.F. 2002. Puroindolines: the molecular genetic basis of wheat grain hardness. In Plant Molecular Biology, vol. 48, pp.633-647. DOI: 10.1023/A:1014837431178.

MORRIS, C.F. - MASSA, A.N. 2003. Puroindoline genotype of the U.S. National Institute of Standards \& Technology Reference Material 8441, Wheat hardness. In Cereal Chemistry, vol. 80, pp. 674-678. DOI: 10.1094/CCHEM.2003.80.6.674.

OURY, F.X. - LASME, P. - MICHELET, C. - ROUSSET, M. - ABECASSIS, J. - LULLIEN-PELLERIN, V. 2015. Relationships between wheat grain physical characteristics studied through near-isogenic lines with distinct puroindoline-b allele. In Theoretical and Applied Genetics, vol. 128, pp. 913-929. DOI: 10.1007/s00122-015-2479-z.

PETERSON, C.J. - GRAYBOSCH, R.A. - BAENZIGER, P.S. - GROMBACHER, A.W. 1992. Genotype and environment effects on quality characteristics of hard red winter wheat. In Crop Science, vol. 32, pp. 98-103. DOI: $10.2135 /$ cropsci1992.0011183X003200010022x.

RAHMAN, S. - JOLLY, J.C. - SKERRITT, J.H. - WALLOSHECK, A. 1994. Cloning of a wheat $15-\mathrm{kDa}$ grain softness protein. In European Journal of Biochemistry, vol. 223, pp. 917-925. DOI: 10.1111/j.14321033.1994.tb19069.x.

SWAN, C.G. - MEYER, F.D. - HOGG, A.C. - MARTIN, J.M. - GIROUX, M.J. 2006: Puroindoline-b limits binding of puroindoline-a to starch and grain softness. In Crop Science, vol. 46, pp. 1656-1665. DOI: 10.2135/cropsci2005.06-0135.

TAHIR, A.R. - NEETHIRAJAN, S. - JAYAS, D.S. SHAHIN, M.A. - SYMONS S.J. - WHITE, N.D.G. 2007. Evaluation of the effect of moisture content on cereal grains by digital image analysis. In Food Research International, vol. 40, pp. 1140-1145.

TAŃSKA, M. - ROTKIEWICZ, D. - KOZIROK, W. KONOPKA, I. 2005. Measurement of the geometrical features and surface color of rapesseds using digital image analysis. In Food Research International, vol. 38, pp. 741-750.

TRANQUILLI, G. - LIJAVETZKY, D. - MUZZI, G. DUBCOVSKY, J. 1999. Genetic and physical characterization of grain texture-related loci in diploid wheat. In Molecular and General Genetics, vol. 262, pp. 846-850. DOI: 10.1007/s004380051149.

TURNBULL, K.M. - TURNER, M. - MUKAI, Y. YAMAMOTO, M. - MORELL, M.K. - APPELS, R. - RAHMAN, S. 2003. The organization of genes tightly linked to the $\mathrm{Ha}$ locus in Aegilops tauschi, the D-genome donor to wheat. In Genome, vol. 46, pp. 330-338. DOI: 10.1139/g02-124.

Received: October 16, 2015 